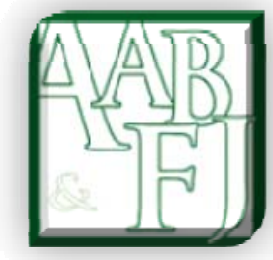

\title{
Changes to a CA Programme - Practitioners' Perspectives
}

\author{
Elizabeth Wheeler ${ }^{1}$, Mary Low ${ }^{1}$ and Grant Samkin ${ }^{1}$
}

\begin{abstract}
This paper examines the perceptions of practitioners of the new directions taken by NZICA with respect to its academic and professional programme requirements to obtain CA Institute membership. The "future viability of any professional body is dependent on continuously attracting new members, ideally the best and the brightest new tertiary graduates”, and this is "undoubtedly the case for New Zealand's professional accounting body, the New Zealand Institute of Chartered Accountants (NZICA)” (Malthus \& Fowler 2009, p. 26). In this study, the concurrent triangulation approach to mixed methods described by Creswell (2009) was used to collect data. This approach enabled the results of the two quantitative and qualitative databases to be integrated and compared.

It was found that accounting practitioners felt the changes made by NZICA may devalue the brand, while the reduction in liberal papers would result in a narrower degree. Overall, accounting practitioners agreed that three to four years of tertiary accounting education was adequate, a broader four-year course would result in a better-rounded graduates. The reduction in the length of the tertiary programme caused concern that future graduates would be less mature. Accounting practitioners also felt that the changes would harm the credibility of NZICA internationally. However, some accounting practitioners did welcome the fact that the NZICA membership requirements will be more aligned with Institute of Chartered Accountants Australia. Accounting practitioners felt that the new technical modules would offer more flexibility. They believed that the four technical modules should repeat the material taught at university, as long as a balance was maintained between technical and practical skills. They also believed that the changes would result in an increased onus on the employer. Additionally, accounting practitioners agreed that on-the-job training should not replace a tertiary qualification in accounting. Accounting practitioners noted that on-the-job training replacing tertiary education meant that individuals who learn better through practical experience would be advantaged. However, if there was no tertiary education, then graduates would face a steep learning curve.
\end{abstract}

\section{JEL Classification: M40}

Keywords: Chartered Accountants, Academic and Professional programme, Accounting Tertiary Education, Practitioners' Perspectives

\footnotetext{
${ }^{1}$ University of Waikato grantsam@waikato.ac.nz
} 


\section{Introduction}

Globally, there are two main routes prospective accountants take to become a member of a professional body: the university route and the vocational route. The University route in New Zealand, Australia, and the United States is similar, whilst the Vocational route provides a pathway for students "who decide to go from school directly into employment, rather than going to university" (Institute of Chartered Accountants of Scotland 2010). This vocational route is generally available in various forms in member countries of the Global Accounting Alliance. The driver behind the vocational route is the opening up of Chartered Accountant (CA) qualifications to school leavers as well as graduates. For example the vocational route in England places a focus on "on-the-job training with established firms", with less emphasis on "formal education" ("Requirements for British Chartered Accountants" 1992, p. 15). Merits of the vocational system include students receiving a salary whilst working, as well as their ability to make use of practical skills whilst learning them ("Requirements for British Chartered Accountants”, 1992). However, the system such as that undertaken by the ICA has been criticised, on the grounds that it results in a less qualified accountant ("Requirements for British Chartered Accountants” 1992).

This study sets out to examine practitioners' perceptions of proposed changes to the New Zealand Institute of Chartered Accountants (NZICA) professional qualifying programme. NZICA will introduce four new modules that on initial view duplicate the technical skills currently taught within tertiary institutions. These modules may remove the incentive for trainee accountants to undertake tertiary education prior to qualifying CA. The implications of this are significant. Firstly, accounting is currently recognised as a profession within New Zealand. However, if educational requirements are reduced and as a result the level of professional status of NZICA decreases, public trust in accounting may fall. Secondly, if accountants are no longer required to hold tertiary qualifications in accounting, employees may favour potential tertiary qualified employees.

This paper has two main research objectives. First, to investigate the importance of accounting tertiary education as a requirement of entry for an accounting body; and second, to examine the views of senior accounting partners and practitioners regarding the new directions being taken by NZICA. The paper is structured as follows. The purpose of tertiary accounting education is examined. Thereafter the New Zealand accounting profession is reviewed. This included an examination of the current academic and professional requirements as well as detailing the proposed academic and professional requirements. The method used in the study is then detailed before the results are discussed. The findings are then discussed and the paper concluded.

\section{Purpose of accounting tertiary education}

The International Federation of Accountants noted that "the goal of accounting education and experience is to produce competent professional accountants" (International Federation of Accountants Education Committee 2003, p. 3). Competence is defined by the International Federation of Accountants Education Committee (1998, p. 1) to be "the ability to perform the tasks and roles expected of a professional accountant, both newly qualified and experienced, to the standard expected by employers and the general public. Flood and Wilson (2008, p. 226) agree, noting that "programmes need to develop a diverse range of skills so that students will ultimately be competent professionals throughout their careers and will have the capacity to adapt to change in every aspect of their professional lives”. Furthermore, the Accounting Education Change Commission (AECC) (1990, p. 2) noted that: 
...accounting programs should prepare students to become professional accountants, not to be professional accountants at the time of entry to the profession. At the time of entry, graduates cannot be expected to have the range of knowledge and skills of experienced professional accountants. To attain and maintain the status of a professional accountant requires continual learning. Therefore, pre-entry education should lay the base on which life-long learning can be built. In other words, graduates should be taught how to learn.

For many countries internationally, the accounting profession operates with a "dual prequalification education system, whereby the prospective member typically completes a degree within the higher education system and then progresses to further study and training under the auspices of the relevant professional body" (Flood \& Wilson 2008, p. 226). According to Zraa, Kavanagh and Hartle (2011, p. 3), the "major objective of accounting education is to prepare students for workplaces". The AECC identified that the purpose of tertiary level education was to "equip accounting students in entering graduate level business work, thus preparing students with a more comprehensive range of skills and attributes" (AECC 1990, p. 2).

Gammie, Cargill and Hamilton (2010, p.7) identify the "requirement for accounting graduates and trainees to develop appropriate skills and competencies to meet the changing requirements of the profession”. Flood and Wilson (2008, p. 225) believe that accounting education must "foster among students a personally developed understanding of the principles and concepts which underpin accounting and business practices”. They also write there has been "much debate about the nature and form of pre-qualification education required preparing prospective professional accountants for challenging and dynamic professional careers” (p. 225). Review reports issued worldwide by professional accountancy bodies and employers "have delineated the desired learning objectives of pre-qualification programmes” (Albrecht \& Sack 2000; Bedford et al. 1986; Flood \& Wilson 2008; Kullberg et al. 1989). From these reports, it is "now recognised that pre-qualification programmes, whether in the higher education system or operated by/for professional bodies themselves, must move away from their traditional focus of imparting large volumes of technical knowledge" (Flood \& Wilson 2008, p. 225). Paisey and Paisey (2010) reflected on how, almost two decades ago, the Accounting Education Change Commission (AECC 1990) developed "a list of fifty-five capabilities that it believed were required by accounting graduates" (p. 89). The list "encompassed knowledge and skills, as well as wider curricular aspects, in the belief that a university education in accounting would be deficient if it only concentrated on knowledge acquisition and technical skills” (Paisey \& Paisey, 2010, p. 89). In 2010, Paisey and Paisey developed a list of skills based on the most frequently cited skills required by accountants. Their list of skills has been summarised in Table 1 . The list provided by Paisey and Paisey (2010) has been extended by reviewing recent as well as other relevant literature on accounting education. Behavioural skills were newly identified (see Table 1new skills and research that are more recent are in italics). 
Table 1. Review of accounting and business education literature on skills

\begin{tabular}{|c|c|}
\hline Skill & References discussing this skill \\
\hline $\begin{array}{l}\text { Ability to extract and } \\
\text { analyse information from a } \\
\text { variety of sources }\end{array}$ & $\begin{array}{l}\text { Lindberg 1999; Kovar \& Evans 2001; Hunton 2002; IAESB 2003, 2006; Ballantine } \\
\text { \& Larres 2004; Tan, Fowler \& Hawkes 2004; Weil, Oyelere \& Rainsbury 2004; } \\
\text { Jackson \& Durkee 2007; Nettleton, Litchfield \& Taylor 2008; Zraa, Kavanagh \& } \\
\text { Hartle 2011; }\end{array}$ \\
\hline Computer ability & $\begin{array}{l}\text { Marriott \& Mellett 1994; Sangster \& Mulligan 1997; Bhattacharjee \& Shaw 2001; } \\
\text { Donelan \& Philipich 2002; IAESB 2003; Paisey \& Paisey 2005; Potter \& Johnston } \\
\text { 2006; Kavanagh \& Drennan } 2008\end{array}$ \\
\hline Critical thinking & $\begin{array}{l}\text { Friedlan 1995; Nikolai 1996; Manninen 1997; Nathan \& Dunn 1997; Crumbley \& } \\
\text { Smith 2000; Kern 2001; Hunton 2002; Wolcott, Baril, Cunningham, Fordham \& St. } \\
\text { Pierre 2002; Ferguson, Collison, Power \& Stevenson 2005; Kealey, Holland \& } \\
\text { Watson 2005; Kavanagh \& Drennan 2008; Nettleton, Litchfield \& Taylor 2008; } \\
\text { Samkin \& Francis 2008; Gammie, Cargill \& Hamilton 2010; Zraa, Kavanagh \& } \\
\text { Hartle } 2011\end{array}$ \\
\hline Oral communication & $\begin{array}{l}\text { Simons \& Higgins 1993; Zaid \& Abraham 1994; Smythe \& Nikolai 1996, 2002; } \\
\text { Cheng \& Saemann 1997; Weisenfeld \& Robinson-Backmon 2001; IAESB 2003, } \\
\text { 2006; Keim \& Grant 2003; Grace \& Gilsdorf 2004; Gardner, Milne, Stringer \& } \\
\text { Whiting 2005; DeLange et al. 2006; Kavanagh \& Drennan 2008; Milner \& Hill } \\
\text { 2008; Nettleton, Litchfield \& Taylor 2008; ACCA 2011; Zraa, Kavanagh \& Hartle } \\
\text { 2011 }\end{array}$ \\
\hline Problem-solving skills & $\begin{array}{l}\text { Simons \& Higgins 1993; Breton 1999; Maher 2000; Davis, Hwang \& Shoaf 2001; } \\
\text { Phillips 2001; Hunton 2002; IAESB 2003, 2006; Clayton \& Still 2004: Tan, Fowler } \\
\text { \& Hawkes 2004; Kennedy \& Sorensen 2006; DeLange et al. 2006; Prensky 2007; } \\
\text { Hurt 2007; Kavanagh \& Drennan 2008; Milner \& Hill 2008; Nettleton, Litchfield \& } \\
\text { Taylor 2008;Samkin \& Francis 2008; ACCA 2011; Zraa, Kavanagh \& Hartle } 2011\end{array}$ \\
\hline Written communication & $\begin{array}{l}\text { Simons \& Higgins 1993; Zaid \& Abraham 1994; Smythe \& Nikolai 1996; Sawyer, } \\
\text { Tomlinson \& Maples 2000; Weisenfeld \& Robinson-Backmon 2001; IAESB 2003, } \\
\text { 2006; Cleaveland \& Larkins 2004; Gardner et al. 2005; DeLange et al. 2006; } \\
\text { Kavanagh \& Drennan 2008: Milner \& Hill 2008; Nettleton, Litchfield \& Taylor } \\
\text { 2008; ACCA 2011; Zraa, Kavanagh \& Hartle 2011; }\end{array}$ \\
\hline Behavioural skills & $\begin{array}{l}\text { Lahn \& Jensen 2006; Kavanagh \& Drennan 2008; Nettleton, Litchfield \& Taylor } \\
\text { 2008; ACCA 2011; Gammie, Cargill \& Hamilton } 2010\end{array}$ \\
\hline
\end{tabular}

Updated from: Paisey and Paisey 2010, p. 105.

\section{New Zealand Accounting Profession}

The "future viability of any professional body is dependent on continuously attracting new members, ideally the best and the brightest new tertiary graduates", and that this is "undoubtedly the case for New Zealand's professional accounting body" (Malthus \& Fowler 2009, p. 26). Informal discussions revealed that some accounting practitioners believe that the recent changes made by NZICA to their academic and professional requirements may be in order to increase membership rates due to competition with CPA Australia, which only requires three years of accounting education (CPA Australia, 2011).

In New Zealand, Malthus and Fowler (2009) indicate that it is "apparent that professional accountants are in high demand, however many students are reluctant to make chartered accountancy their first career choice” (p. 26). They suggest that increasing the academic and professional requirements from three to four years of a degree programme led to "declining numbers of domestic accounting graduates in New Zealand" (p. 31). Additionally, it was perceived by "some tertiary accounting students" that the "costs of becoming a CA outweigh the benefits of membership" (Malthus \& Fowler 2009, p. 26). Furthermore, they found that a number of tertiary students considered becoming Associate Chartered Accountants (ACAs) instead of CAs because the length of degree level study 
required to become an ACA member was only three years, versus the four years to become a CA. Tan and Laswad (2006, p. 167) provide a different concern, where it has been expressed "within the accounting profession that recruits into the profession may not be of exceptional quality and that the accounting discipline may by losing its appeal to bright business students”.

\section{Current academic and professional requirements for membership}

To qualify as a Chartered Accountant in New Zealand is a three-step process. This includes the completion of a recognised academic programme, a practical experience component and a professional competence programme. The academic component requires the completion of four years' degree level study. This includes completing a bachelor's degree at an NZICAaccredited tertiary institution of specified accounting and business topics, together with 30 credits of liberal studies (NZICA 2010a).

The practical experience component requires a candidate to complete three years of practical experience at an Approved Training Organisation (ATO). This includes "General Practical Experience" which is "one year of relevant accounting experience" which can be "completed before, during or after the completion of the academic requirements", as well as two sets of "Specified Practical Experience" which run for a period of twelve months each (NZICA 2010a, p. 1).

Finally, the professional competence programme must be completed. This can be broken down into the Foundations Programme, the Professional Accounting School (PAS) and Professional Competence Examination (PCE) Programme. The Foundations Programme comprises a number of self-study plans, a one-day assessed workshop and an open book exam. The overall goal of the Foundation programme is to "assess a provisional member's understanding and appreciation of the authority for and the structure of, the accounting profession, ethical issues and current issues of a non-technical nature influencing the accounting profession” (NZICA 2010a, p. 1). The PAS Programme which follows on from the Foundations Programme is a part-time self-study programme structured around six twoday workshops and is completed over a seven-month period (NZICA 2010a). Candidates sit the PCE case-study based examination once all PAS workshops have been completed (NZICA 2010a).

\section{New academic and professional requirements}

In 2010, NZICA collaborated with the Institute of Chartered Accountants Australia (ICAA 2011) in order to "create a powerful alliance between the two organisations and cement the Chartered Accountant qualification as the foremost professional designation for accountants within the Asia-Pacific region” (NZICA 2010b, p. 3). The overall goal of the collaboration is to "deliver a 21st century, world class programme that meets the future needs and expectations of candidates and members, while retaining the proven quality, technical rigour and practical content of our existing qualifying programme” (NZICA 2010b, p. 3). This collaboration requires the development of a joint qualifying programme to be delivered jointly by the NZICA and ICCA from 2013 (NZICA 2011a, 2011b). The new program will only take six years to complete. It will require the completion of a three-year degree followed by the CA Programme undertaken during the practical experience component (three years) (NZICA 2010b).

\section{Academic component}

The main difference between the current and the new academic and professional requirements for membership is the time needed to complete the requirements, with the 
current seven years being reduced to six years. NZICA now requires that an approved three year bachelor's degree is undertaken, as well as "recognised courses in the following topics delivered by an NZICA accredited tertiary institution: Financial Accounting, Management Accounting, Taxation, Auditing and Assurance, Business Finance/Treasury, Economics, Statistics, Organisational Management, Commercial and Corporate Law and Accounting Information Systems" (NZICA 2010b, p. 6). There will be a change to the Statement of Learning Objectives (SLOs) used for the degree requirements, with "what to teach (five advanced topics) and how to teach it (applied case studies)" being reduced (NZICA 2010b, p.6). Furthermore, although "an accounting major would be a preference", the new programme makes this no longer essential, thus enabling "students with non-accounting degrees to more easily meet the Institute’s requirements” (NZICA 2010b, p. 6).

\section{Professional component}

The current fourth year of academic study will be replaced with four technical modules which are studied part-time in conjunction with work experience. The current Professional Competence Programme (Foundations and PAS/PCE2) will be replaced with a Capstone module (NZICA 2010b). The new program will utilises online learning delivery making access easier for those candidates working at regional ATOs.

The four technical modules are Audit and Assurance (AAA), Financial Accounting and Reporting (FIN), Management Accounting and Finance (MAAF) and Taxation (TAX NZ) (NZICA 2011a, p. 1). These are "intended to provide candidates with a solid understanding of the core accounting areas", and are based on "learning design best practice that recognises an active, constructive role for candidates” (NZICA 2010b, p. 7). The technical modules should entail "12 weeks of study each" with an "exam in week 13", and these would be available "twice in a rolling 12 month period", (NZICA 2011a, p. 1). The study time expected is "120 hours of study per module" with "one voluntary virtual workshop per module" and "three assessments during each module (NZICA 2011a, p. 1).

The Capstone Module is described to be a "practical, integrated case study approach", with the "application of technical knowledge and professional skills and competencies" (NZICA 2011a, p. 1). The Capstone module is intended to "consolidate the learning from the technical modules and draws heavily on work experience"; in this module "candidates will focus on applying what they have learned to solve real business problems and on demonstrating the key non-technical competencies” (NZICA 2010b, p. 7). The overall objective of the Capstone module is "to develop competence in integrating knowledge, skills, values and ethics so that candidates can deliver sound professional judgement within a business context” (NZICA 2010b, p. 9). The Capstone module will develop the competencies currently developed by the NZICA PAS in "140 hours of study over 14 weeks with an exam in week 17” (NZICA 2011a, p. 1). This programme will be delivered through "blended learning delivery, using an online interactive program between workshops" alongside "three mandatory face-to-face weekend workshops of 11/2 days each" (NZICA 2011a, p. 1). The Capstone module also entails "two internal assessments as part of workshops two and three" and the module will be made available "twice a year" (NZICA 2011a, p. 1). NZICA's current and new academic and professional requirements for becoming a Chartered Accountant are summarised in Figure 1. 
Figure 1. Comparison between current and new requirements of NZICA

Current Program

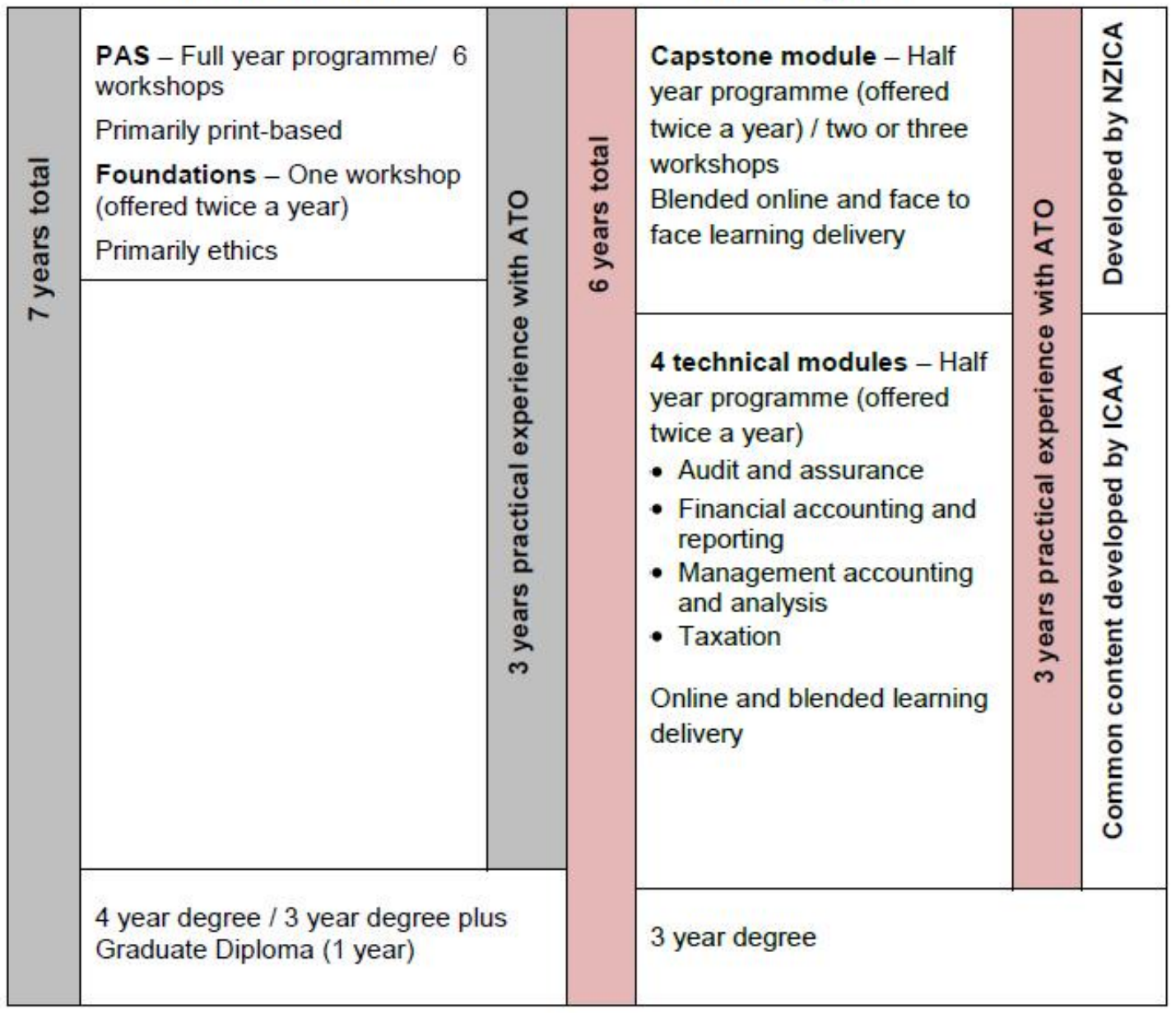

Source: NZICA 2010a

\section{Method}

A mixed method approach combining quantitative and qualitative research techniques was used to collect the data used in this study. A mixed methods approach is described to be a procedure for collecting, analysing and mixing both quantitative and qualitative data during the research process within a single study in order to better comprehend a research problem (Creswell 2002). Researchers often utilise mixed methods as it is believed to broaden understanding (Creswell 2009). Furthermore, some researchers believe that neither quantitative nor qualitative methods are adequate by themselves to reflect the research problem being investigated, but when they are used in combination they complement each other and allow for a more comprehensive analysis (Tashakkori \& Teddlie 1998).

This study utilises the concurrent triangulation approach to mixed methods described by Creswell (2009) as the most commonly used of the six major mixed methods models. In this approach, the "researcher collects both quantitative and qualitative data concurrently and then 
compares the two databases to determine if there is convergence, differences, or some combination" (Creswell 2009, p. 213). This model results in the quantitative and qualitative methods being used as a "means to offset the weaknesses inherent within one method with the strengths of the other (or, conversely, the strength of one adds to the strength of the other)" (Creswell 2009, p. 213).

In this design, priority was given to the qualitative component, because the qualitative research represents the major aspect of data collection and analysis in the study, focusing on eighteen in-depth interviews. A quantitative component was provided through the survey, which was distributed online, in which sixty two responses were analysed. The mixing in the course of this approach was to integrate and compare the results of the two databases side by side in the results discussion.

\section{Survey instrument}

The survey instrument was designed specifically for New Zealand participants. The survey instrument detailed the research objectives which included a table comparing the current and new academic and professional requirements. The questionnaire contained a mix of tick-box, Likert-type, and open-ended questions. As the questionnaire was aimed at practitioners, it was felt that they would be in a position to provide further clarification on certain of their responses. The data were collected anonymously. Demographic data collected included information on gender, age bracket, qualification held, subject major, years' work experience and accounting body affiliation.

\section{Data Collection}

\section{Electronically administered survey}

The survey questionnaire was web-based and accessed through a URL, which was sent to contact people within accounting firms in New Zealand. The purpose of this survey was to investigate and determine chartered accountants' views on the change in entry requirements for a CA, as well as their perceptions of the impact of these changes on the validity of the accounting profession. For both ease of circulation and maximum penetration within the firm, the surveys were sent to one known person from each firm who had the resources to circulate the questionnaire amongst employees through email. A survey questionnaire was used as this is a tool which increases response due to its ease of completion. It also helped participants to have a sense of confidentiality, which may have resulted in more honest responses. A further advantage of a web-based survey was that participants' responses were automatically stored in a database and could be easily transformed into numeric data in Excel format.

The questionnaire comprised twenty-one questions organised into seven sections. The first section of the survey explained the purpose of the research and outlined the general information regarding the survey. The second section asked questions related to the demographics of the participants. The third section asked questions related to the changes which NZICA has made to its academic and professional requirements, and how the changes may affect aspects of the accounting profession, such as the barrier to entry. The fourth section asked questions relating to the four new technical modules, and the fifth section asked questions relating to on-the-job training. The sixth section examined the applied nature of accounting education, and finally, the seventh section provided the opportunity for any additional comments.

The demographics of the respondents are detailed in Table 2. The majority of respondents were between 21 and 29 years of age, held a four year university degree, had been practising between one and five years and were NZICA members. 
Table 2. Respondent demographics

\begin{tabular}{|c|c|c|}
\hline & Characteristic & Frequency (\%) \\
\hline \multirow[t]{2}{*}{ Sex } & Male & 47 \\
\hline & Female & 53 \\
\hline \multirow[t]{5}{*}{ Age } & Under 21 years & 3 \\
\hline & 21-29 years & 61 \\
\hline & 30-39 years & 21 \\
\hline & 40-49 years & 8 \\
\hline & $50+$ years & 6 \\
\hline \multirow[t]{6}{*}{ Qualification } & University Degree (4 Years) & 57 \\
\hline & University Degree (3 Years) & 8 \\
\hline & $\begin{array}{l}\text { University Degree and Graduate Diploma (3 Years } \\
+1 \text { Year) }\end{array}$ & 12 \\
\hline & Diploma (2 Years) & 3 \\
\hline & Secondary School Qualification & 8 \\
\hline & Other (Please Specify) & 12 \\
\hline \multirow{4}{*}{$\begin{array}{l}\text { Years practicing as } \\
\text { an accountant }\end{array}$} & Less than one year & 8 \\
\hline & One to five years & 50 \\
\hline & Five to ten years & 24 \\
\hline & More than ten years & 18 \\
\hline \multirow{6}{*}{$\begin{array}{l}\text { Accounting Body } \\
\text { Affiliation }\end{array}$} & NZICA Student Affiliate & 11 \\
\hline & NZICA Chartered Accountant Membership & 68 \\
\hline & $\begin{array}{l}\text { NZICA Associate Chartered Accountant } \\
\text { Membership }\end{array}$ & 10 \\
\hline & $\begin{array}{l}\text { South African Institute of Chartered Accountants } \\
\text { (SAICA) }\end{array}$ & 2 \\
\hline & $\begin{array}{l}\text { Institute of Chartered Accountants in England and } \\
\text { Wales (ICAEW) }\end{array}$ & 2 \\
\hline & Other & 8 \\
\hline
\end{tabular}

Semi-structured in-depth interviews

In addition to the survey instrument and to provide a richness to the data gathered, a number of semi-structured in-depth interviews were conducted with twelve partners and managers and one human resource manager of the selected Big Four firms, and five partners and managers from small to medium firms. These partners were spread across the three disciplines: Accounting and Advisory, Taxation and Audit. The interviews were followed by an open-ended discussion format. The interviews comprised sixteen core questions that provided a structure and ensure that each interviewee had the opportunity to answer each core question. This form of interview is described to be more structured than an informal conversational interview, but the slightly informal structure allows the researcher to develop 
a relationship with the interviewees so that follow-up questions could be asked based on responses given (Turner 2010).

Once all the interviews were conducted and transcribed, the transcripts were coded thematically. Codes were developed based on the emerging data collected from the interviewees (Creswell 2009). This resulted in the themes becoming interrelated in order to achieve a higher level of analysis and understanding, and reducing any pre-conceptions of which codes may be discovered (Glaser 1978, as cited in Fernández 2004).

\section{Results}

This section of the paper describes and discusses the findings from both the electronically administered survey (respondents) and semi-structured interviews (interviewees/participants). The findings will be discussed under the following broad subheadings: 'Perceived significance of NZICA's new directions'; 'Length and form of tertiary education'; 'Four new technical modules'; and 'On-the-job training'.

\section{Perceived significance of NZICA's new directions}

Gammie and Kirkham (2008, p. 356) noted that any change in the "educational composition of the members of a professional group may adversely impact upon that group's status and standing in society". Based on this, it was deemed important to investigate whether accounting practitioners thought the proposed changes were likely to have a significant impact on different stakeholders. Respondents were asked to rate on a Likert-type scale of 1 to 9 where 1 depicts "Very significant" and 9 "Not Significant" to the question: How significant are the new directions for NZICA professional membership on the following groups? The two groups were current and future NZICA members.

Overall, respondents felt that the significance of the new directions for NZICA professional membership was neutral for current members of NZICA. However, with a mean of 2.2, respondents believed that the new directions were likely to be significant for future NZICA members. This view was confirmed in part with the interviews with Participant ' $E$ ' noting the changes are "significant for students and will have an impact on [our] business." An interviewee (Participant ' $\mathrm{H}$ ') felt the three year degree means some credibility would be lost, while another (Participant ' $M$ ') believed the change was devaluing the brand. Participant ' $R$ ' observed "they have decided that they will dumb down the qualification so that they can be the same as CPA." Participant ' $\mathrm{O}$ ' noted that "the institute is getting further and further involved in education and I just think that is bad news. We're a membership body, not an educational body.” Four participants noted that having that fourth year was quite maturing. Participant ' $F$ ' recognised that "the modules will have a huge drain over the three years. Their time (graduates) and our time- that appears to be an extra cost. And who knows, that may have to be passed onto the graduates because they won't be around as much to work."

Respondents were then asked how significantly do they perceive the NZICA Chartered Accountant academic requirements moving from a 4 year to a 3 year degree requirement on the following: Professional status and credibility of NZICA in New Zealand, Professional status and credibility of NZICA internationally, Employers/Potential Employers, Clients/Potential Clients; and Future students considering accounting as an option. The results are detailed in Table 3. 
Table 3. Impact of moving to a three-year degree on stakeholders

\begin{tabular}{lr}
\hline & Mean \\
\hline Professional status and credibility of NZICA in New Zealand & 3.6 \\
Professional status and credibility of NZICA internationally & 3.4 \\
Employers/ Potential Employers & 5.9 \\
Clients / Potential Clients & 5.6 \\
\hline Future students considering accounting as an option & 2.6 \\
\hline
\end{tabular}

From the above findings it would appear that respondents felt that the changes were reasonably significant for the professional status and credibility of NZICA both within New Zealand (with a mean of 3.59) and internationally (with a mean of 3.39), and well as future students considering accounting as an option (with a mean of 2.61). Interview participants shed further light on the results detailed above. A number of interviewees generally believed that the changes would be desirable for students as the formal education programme is shortened. However this was not universally accepted. Other participants felt that shortening the formal education programme would have a negative impact on students. Reasons posited for this position include: a lack of opportunity to develop research skills; a less broad degree which impacts on a well-rounded education; and maturity issues. As Participant ' $A$ ' remarked, accounting firms “can’t afford immature grads” because "you need a certain level of maturity to deal with clients."

A further concern raised was the increased emphasis that would need to be placed on onthe-job training. As Participant ' $M$ ' noted, the changes would "cause disruption from a work perspective as people will need more time off and people will have less technical knowledge so will need more on the job training so will cost the firm with that too." Furthermore, Participant ' $K$ ' believed that the changes will place "more onus onto the employer".

Flood and Wilson (2008, p.226) argue that the "specialised education of members is a key trait of professions". Using a five-point Likert scale where one (1) depicts 'Strongly Disagree', and five (5) 'Strongly Agree', respondents were asked: To what extent do you agree that the new direction taken by NZICA will have a detrimental impact on the professional status of current members of NZICA? The responses were relatively evenly distributed: $27 \%$ disagreed, $31 \%$ either agreed or disagreed, while $31 \%$ agreed with the question. The mean score was 3.06 (SD 1.02), suggesting respondents did not believe that the new direction taken by NZICA would have a detrimental impact on the professional status of current NZICA members.

Using a seven-point Likert scale where one (1) depicts "Strongly Disagree" and seven (7) "Strongly Agree", respondents were asked to assess: To what extent do you agree that the new direction taken by NZICA will have a detrimental impact on the employability of future members either nationally or internationally? The respondents' perceptions are detailed in Figure 2. 
Figure 2. Respondents' perceptions of whether the new direction taken by NZICA will have a detrimental impact on the employability of future members

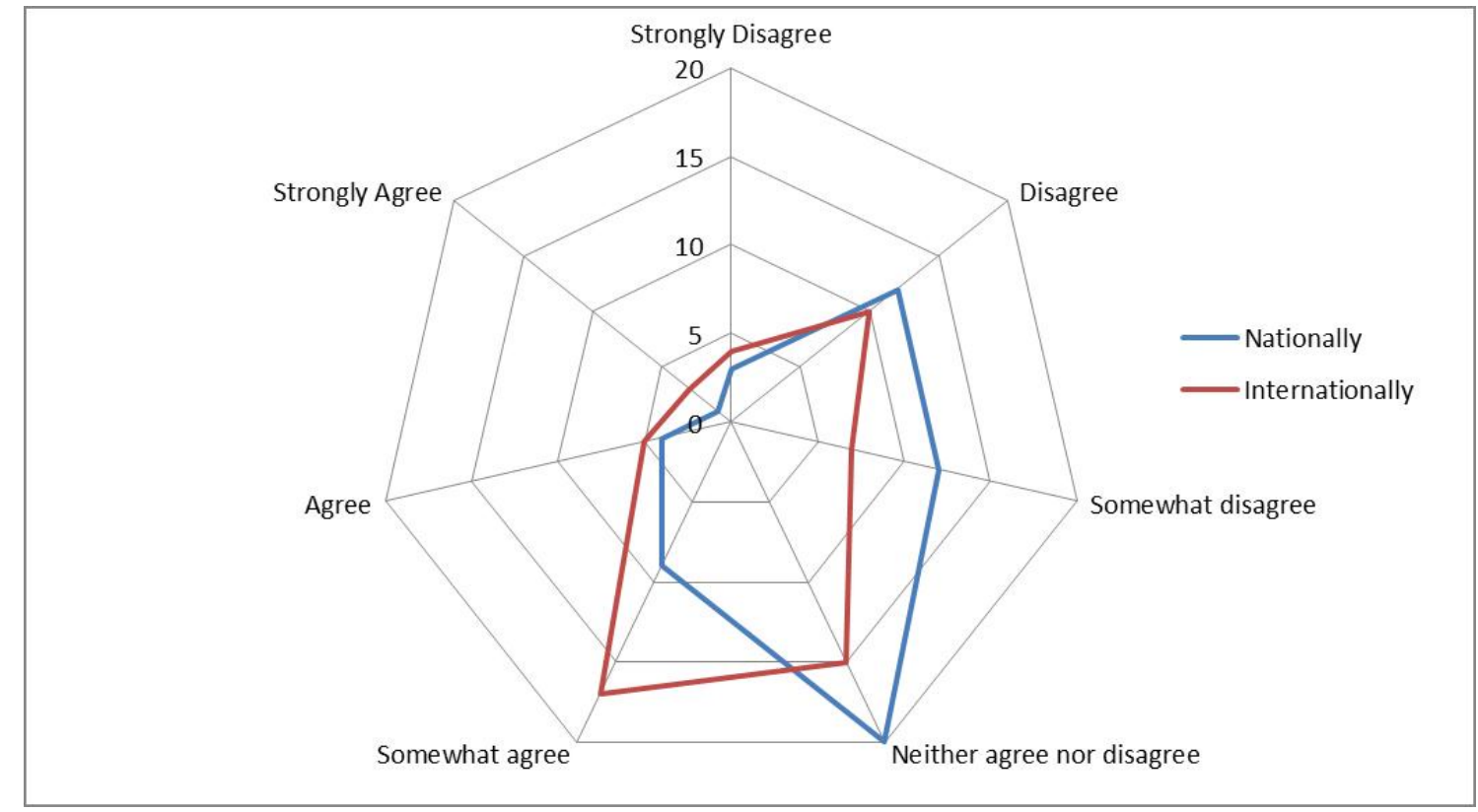

Interview participants held mixed views as to how the changes would affect the professional status of the NZICA. A summary of the differing views are detailed in Table 4.

Table 4. Summary of participants' views of how the new directions taken by NZICA will affect the professional status currently held by NZICA

\begin{tabular}{llll}
\hline \multicolumn{1}{c}{ Positive and neutral aspects } & \multicolumn{1}{c}{ Negative aspects } & \\
\hline $\begin{array}{l}\text { Nationally, the changes will not be too } \\
\text { bad }\end{array}$ & 4 & May make trust harder & 3 \\
$\begin{array}{l}\text { People who are not NZICA members } \\
\text { will not notice a difference }\end{array}$ & 5 & $\begin{array}{l}\text { Changes may be seen as taking a step } \\
\text { back, may result in negative perceptions }\end{array}$ & 6 \\
$\begin{array}{l}\text { Change may not effect professional } \\
\text { status }\end{array}$ & 6 & $\begin{array}{l}\text { Harder to attract people considering } \\
\text { doing the degree }\end{array}$ & 3 \\
$\begin{array}{l}\text { Alliance with Australia will enhance the } \\
\text { status }\end{array}$ & 3 & $\begin{array}{l}\text { Is important to maintain bar and } \\
\text { standards }\end{array}$ & 2 \\
\begin{tabular}{l} 
The right person is still the right person \\
\hline
\end{tabular} & 3 & & \\
\hline
\end{tabular}

Length and form of tertiary education

Albrecht and Sack (2000, p. 1) noted that practising accountants "would not major in accounting if pursuing their education over again.” In order to establish whether this view of Albrecht and Sack (2000) applied in New Zealand, respondents were asked: To what extent do you agree that a tertiary qualification in accounting benefited you in your career? $35 \%$ of respondents strongly agreed that their tertiary education benefited them in their career while $37 \%$ agreed with the question. The responses suggest that the majority of respondents would still major in accounting if they undertook their education over again. 


\section{Barriers to entry}

Flood and Wilson (2008, p. 236) argue that a profession is defined by its barrier to entry, and that if the "quantity as opposed to the quality of new members" becomes dominant, it could threaten the position of the body. In response to this concern respondents were asked: To what extent do you agree that the reduction of tertiary education from four years to three years will reduce the barrier to entry for a Chartered Accountants career pathway?

Overall, respondents neither agreed nor disagreed, with a mean of 3.47, that the reduction of tertiary education from four years to three years would reduce the barrier to entry for a Chartered Accountant's career pathway. However, this included more than half the respondents (60\%) either strongly agreeing or agreeing that the reduction of tertiary education to three years would reduce the barrier to entry for a CA career pathway.

Interview participants held mixed perceptions as to how high the barrier to entry was to obtaining a CA qualification. They also had mixed views as to whether the barrier to entry would be affected by the changes made by NZICA, along with whether the alteration to the barrier to entry would be a good thing or not. Participant 'A' saw a high barrier to entry as a result of competitive pressure, but only saw this barrier existing within the Big Four firms and not so much in the small firms. Participant ' $\mathrm{B}$ ' did not see a high barrier to entry, noting that "if students have already done their degree and know what they want, they can usually attain the CA. The degree is the deciding part.” Three participants thought that, despite a high barrier to entry, there are nevertheless good numbers going through. The majority of participants viewed the high barrier as a positive aspect because better quality individuals enter the profession. Participant 'I' thought that "it is tough... it's a good thing; there are a lot of people who portray themselves as a competent accountant when in fact they are rubbish... So in some ways, I think it needs to be tougher. But it also has to be relevant.” Fifty percent of participants thought the barrier to entry will be lowered as a result of the changes, but Participant ' $G$ ' thought "it shouldn't impact overall on the final qualification.” Furthermore, Participant ' $\mathrm{K}$ ' felt that the "reduction in the length will make it easier, but the reluctance from employers will balance it out.”

\section{Preparation for admission to the profession}

The literature review revealed that there was little consensus on how many years of tertiary education, majoring in accounting, would be suitable to prepare an accountant for admission into a professional body. For instance, Whitham (1974) noted that while the Beamer Committee 1969 Report indicated that at least five years of college study was required, he did not believe that time was the issue but rather the bachelor's programmes' contents were important. Furthermore, Mathews (2001, p. 120) noted that "the question of how long a programme should be is an interesting one.” Due to there being no clear consensus in the literature, respondents were asked: How many years of tertiary education, majoring in accounting, do you think would be adequate to prepare students for a career in accounting? $59 \%$ of the respondents believed three years was adequate, $2 \%$ thought no tertiary education was needed, $3 \%$ believed only two years were needed, while $36 \%$ stating that at least four years of tertiary education in accounting was needed to prepare students for a career in accounting. However, no respondents believed that five or six years were needed in order to adequately prepare students for a career in accounting.

Responses to the open ended question: Do you have any comments you would like to add regarding the reduction of tertiary education from four years to three years? provide additional insights. Generally respondents supported the four year tertiary requirement. One respondent explained their position as follows: 
Generally I think that over the four years of study students develop depth and breadth to their learning and research skills which stand them in good stead in the workplace. I believe strongly in the importance of coupling both academic learning and development of practical skills. I think there is a widespread perception in society that university degrees fit us for the world, however it is the combination of university learning, practical training and life experience that give us the strength to serve our communities as professionals.

However some respondents expressed their frustrations with their fourth year of study, with comments such as "four years was a waste of time" and "for me the fourth year did not add any value to my degree or to my accounting career”. Another respondent noted that:

University provides a good basic knowledge of accounting. However, once you enter the workforce it is like starting over again. There is a lot to learn and I don't necessarily think the extra year at university helped in preparing me for this.

There is debate whether there should be more, rather than less, years specialising in accounting in a tertiary institution (Reeve 1983). These major issues included competency, efficiency, breadth and prestige (Reeve 1983). To test this position a seven-point Likert scale where one (1) depicts 'Strongly Disagree', and seven (7) depicts 'Strongly Agree' was used with the following statement: To what extent do you agree with the following statements, with regard to the NZICA (CA) requirement of four years of tertiary education? The results are detailed in Table 5.

Interview participants expressed preference for three or four years of accounting-related tertiary education. Those that supported the four year programme saw higher level thinking as important. As Participant ' $\mathrm{K}$ ' noted: "the fourth year seems to get into the more specialised learning and high level thinking." Participant 'A' liked the fact the four year degree gave the chance to do some liberal papers along with the fundamentals, and hoped NZICA will keep "the core subjects with some flexibility". Maintaining the liberal paper component was seen as very important by the majority of interview participants. As Participant 'B' explained, liberal papers are good "because you learn different skills in those papers and you also interact with different people, not just accountants." Similarly, Participant ' $O$ ' felt that "any non-core subject helps you to understand what society is about". Furthermore, Participant ' $\mathrm{I}$ ' believed that there is "only so much you can learn technically with accounting. And that's not what people come to chartered accountants for; they come for perspectives and advice." 
Table 5. To what extent respondents agree with the statements, with regard to the NZICA (CA) requirement of four years of tertiary education

\begin{tabular}{|c|c|c|c|c|c|c|c|c|c|c|}
\hline$\#$ & & $\begin{array}{l}\text { Strongly } \\
\text { disagree }\end{array}$ & Disagree & $\begin{array}{c}\text { Somewhat } \\
\text { disagree }\end{array}$ & $\begin{array}{c}\text { Neither } \\
\text { agree } \\
\text { nor } \\
\text { disagree }\end{array}$ & $\begin{array}{c}\text { Somewhat } \\
\text { agree }\end{array}$ & Agree & $\begin{array}{l}\begin{array}{c}\text { Strongly } \\
\text { agree }\end{array} \\
\text { age }\end{array}$ & Responses & Mean \\
\hline 1 & $\begin{array}{l}\text { High level of world class } \\
\text { standards }\end{array}$ & 0 & 1 & 1 & 7 & 16 & 30 & 5 & 60 & 5.47 \\
\hline 2 & $\begin{array}{l}\text { High level of ability for } \\
\text { accounting graduates to apply } \\
\text { accounting knowledge to work } \\
\text { experience }\end{array}$ & 0 & 1 & 6 & 6 & 15 & 26 & 6 & 60 & 5.28 \\
\hline 3 & $\begin{array}{l}\text { High level of flexibility of } \\
\text { qualification }\end{array}$ & 1 & 6 & 6 & 8 & 23 & 14 & 2 & 60 & 4.60 \\
\hline 4 & $\begin{array}{l}\text { high level of alignment with } \\
\text { other professional accounting } \\
\text { bodies worldwide }\end{array}$ & 0 & 2 & 3 & 14 & 18 & 19 & 4 & 60 & 5.02 \\
\hline 5 & $\begin{array}{l}\text { High level of recognition } \\
\text { worldwide of New Zealand } \\
\text { Chartered Accountants }\end{array}$ & 0 & 2 & 2 & 6 & 20 & 22 & 8 & 60 & 5.37 \\
\hline 6 & $\begin{array}{l}\text { High level of incentive for future } \\
\text { accountants to pursue a CA } \\
\text { membership }\end{array}$ & 1 & 3 & 11 & 6 & 13 & 21 & 5 & 60 & 4.83 \\
\hline 7 & $\begin{array}{l}\text { Solid overall foundation of } \\
\text { accounting knowledge for } \\
\text { accounting graduates }\end{array}$ & 0 & 3 & 3 & 3 & 22 & 23 & 6 & 60 & 5.28 \\
\hline
\end{tabular}

Benefits of an accounting degree

Different countries have different qualification requirements for a person to become a chartered accountant. For example, to obtain an ACA from the ICAEW, candidates do not need to have studied an accounting or finance degree (ICAEW 2011). The survey was therefore used to assess whether participants believed that a degree majoring in accounting was an important criterion in becoming a CA.

Respondents were asked to use a five point Likert scale where (1) depicts 'Strongly disagree' and (5) 'Strongly agree' to respond to the question: To what extent do you agree that an individual would make a more effective accountant through specialising their tertiary education in accounting rather than in other areas? (e.g. majoring in Accounting rather than History). The results suggest that overall, respondents agreed that accountants would be more effective if they majored in accounting, represented by an overall mean of 3.97 which was comprised of $78 \%$ of respondents either agreeing or strongly agreeing with the statement.

Interview participants generally saw their degrees as providing them with benefits. Participant 'A' stated that the tertiary education was good, as "when you come out of university you have a good understanding of the fundamentals." Participant ' $D$ ' said that "the degree helped me to understand a wide variety of things" as well as understanding how "different parts of a business integrate together". Participant ' $\mathrm{J}$ ' also believed that tertiary education "gives you a depth of understanding of where to go to look for things". Similarly, Participant ' $O$ ' believed that tertiary education provided the "skill set to do what I do", adding that tertiary education "helped with being receptive with continuing to learn". Participant ' $R$ ' remarked that their tertiary education was “an absolute godsend”, adding that "I could never, ever have done what I have done without an accounting qualification."

It was interesting to note that Participant ' $\mathrm{M}$ ' thought that "four years of financial accounting was really important" and "cutting it down will devalue the qualification." Participant ' $F$ ' believed that in New Zealand people get a "good solid basis in accounting and also a broader range of subjects so it's not just accounting.” Four participants, including 
Participant ' $Q$ ', believed that their tertiary education in accounting was beneficial as they weren't "ready to go straight into a job straight out of school."

Finally, respondents were asked: To what extent do you agree that the barrier to entry to the accounting profession in New Zealand was too high, before the new direction taken by NZICA, in particular education requirements? Using a five point Likert scale where one (1) depicts 'Strongly disagree' and five (5) 'Strongly agree', respondents generally disagreed (Mean 2.28) that the barrier to entry was too high (in particular with regard to education requirements) before the new directions taken by NZICA. This included $65 \%$ of respondents either strongly disagreeing or disagreeing with the statement. Only one respondent strongly agreed with the statement. The findings are summarised in Figure 3.

Figure 3. To what extent respondents agree that the barrier to entry to the accounting profession in New Zealand was too high, before the new direction taken by NZICA

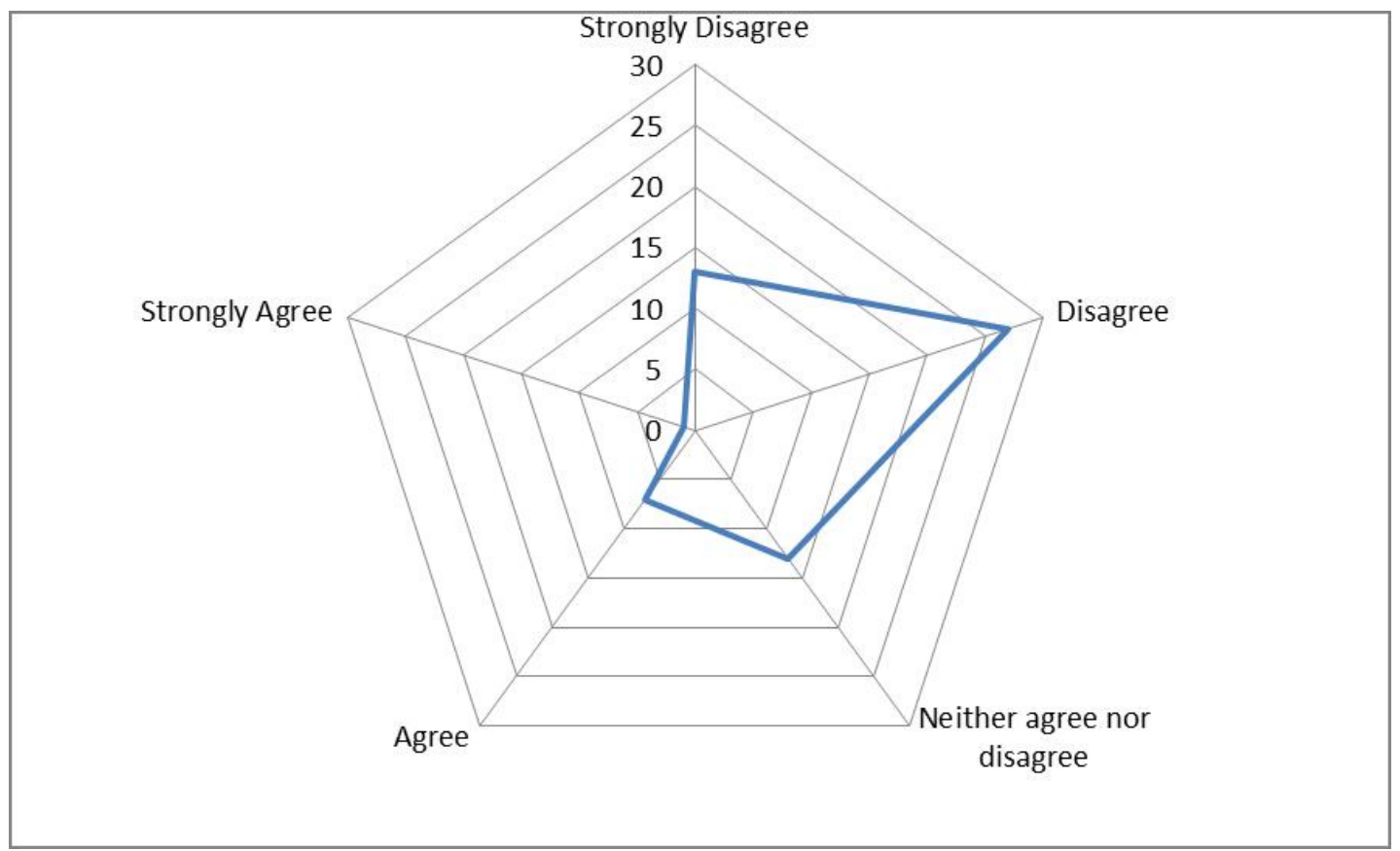

\section{Four new technical modules}

It was identified that additional training for students studying to gain a CA qualification can be difficult due to stakeholders having inadequate resources (Goodridge 2002). However, little information could be found on how training and examinations affect graduate accountants and their workplaces. For this reason, respondents were asked a number of questions concerning the four new technical modules and their implications. A five point Likert scale which ranged from "Strongly Disagree" (1) to "Strong Agree" (5) was used. The mean findings of these questions are summarised in Table 6. 
To what extent do you agree that the four new technical modules will impact negatively on graduate accountants' productivity within an accounting firm (e.g. more study hours required to complete the four technical modules)?

To what extent do you believe that the four new technical modules will repeat the material taught in advanced compulsory topics currently taught in tertiary institutions?

To what extent do you agree that the four new technical modules should entirely replace the compulsory topics of Auditing, Taxation, Financial Accounting and Management Accounting currently taught at tertiary institutions?

To what extent do you agree that the four new technical modules will provide a graduate accountant with more relevant knowledge, competence and skills than the previous Foundations course did?

When respondents were asked: To what extent do you agree that the four new technical modules will impact negatively on graduate accountants' productivity within an accounting firm (e.g. more study hours required to complete the four technical modules), the majority of respondents neither agreed nor disagreed that the four new technical modules would impact negatively on graduate accountants' productivity within an accounting firm, represented by a mean of 2.95. This included $43 \%$ of respondents noting that they neither agreed nor disagreed with the statement.

A follow-up question asked: To what extent do you believe that the four new technical modules will repeat the material taught in advanced compulsory topics currently taught in tertiary institutions? The overall mean of this question was 3.28. Of the 60 respondents who answered the question, $40 \%$ selected the option 'neither agree nor disagree'. However, 43\% agreed that the four new technical modules would repeat the material taught in advanced compulsory topics currently taught in tertiary institution.

In response to the question: To what extent do you agree that the four new technical modules should entirely replace the compulsory topics of Auditing, Taxation, Financial Accounting and Management Accounting currently taught at tertiary institutions?, respondents disagreed, represented by a mean of 2.18, that the four new technical modules should entirely replace the compulsory topics of Auditing, Financial Accounting, Taxation and Management accounting currently taught at tertiary institutions. Of the 60 respondents, 40 either disagreed or strongly disagreed that the new technical modules should replace the compulsory topics taught at tertiary institutions.

However, there was some agreement (mean of 3.23) that the four new technical modules would provide a graduate with more relevant knowledge, competence and skills than the previous Foundations courses did.

A number of the interview participants expressed their concern with the introduction of the four new technical modules. Their concern was based around the additional time that would be required to support their staff through the modules. Most of the participants believed that if the four technical modules run as a continuum from tertiary education, with an added practical component, then it could aid students' learning. Participants were divided as to whether or not the four technical modules would make a better accountant. Participants whose firms operated training programmes did not see the change impacting them too much. 
This can be contrasted with the view of Participant 'A' who said "let's hope that the new modules don't require more time out; we're still trying to run a business here too.” Likewise, over seventy percent of participants believed the changes would affect their resourcing. Concern was expressed how some smaller firms would cope with the additional workload, with Participant 'P' noting that the four new technical modules "will be a burden on small firms”.

\section{On-the-job training}

Howieson (2003, p. 94) noted that it "may be time for university accounting departments to reassess the place of work-based learning in their programmes". To test whether a similar view was held by the respondents they were asked the following question: To what extent do you agree that on-the-job training should replace a tertiary qualification in accounting? On a five point Likert scale where one (1) depicts 'Strongly disagree' and five (5) 'Strongly agree', the mean response to this question was 2.88. Despite this relatively neutral overall result the views were quite polarised, with $39 \%$ of the respondents either agreeing or strongly agreeing with the statement, and $40 \%$ disagreeing or strongly disagreeing with the statement. It was also interesting to note that the respondents who were affiliated with the Institute of Chartered Accountants in England and Wales (ICAEW) agreed with on-the-job training replacing tertiary education, and the respondent who was affiliated with the South African Institute of Chartered Accountants (SAICA) disagreed with the statement. None of the respondents who were Student affiliates with NZICA disagreed or strongly disagreed with the statement, and there was an even spread from the respondents who held a NZICA Chartered Accountant Membership.

Interview participants acknowledged the positive features of on-the-job training including applying knowledge learnt and the aspect of theory plus a practical component to accounting education. However, many participants voiced their concerns that tertiary education needs to be maintained, and that a balance needs to be found between the two styles of learning. Disadvantages identified included the cost implications, time involved and the possibility of this system producing incompetent accountants. The majority of participants did not want to see on-the-job training replacing a tertiary education in accounting, and instead wanted to see a balance between the two options.

Nearly thirty percent of participants noted that with on-the-job training cost recoveries will suffer. Participant ' $M$ ' also noted that "the downside is that we have client deadlines; it will take up a lot of time with seniors and managers to train staff", and that "clients don't want to be a training ground". Participant ' $L$ ' added that "there is going to be a mis-match of the quality of the on-the-job training if everyone is responsible for doing it in their own firms." Participant ' $Q$ ' noted that a benefit of having tertiary education lies with "the people who aren't cut out for it, and who would drop out at university”, adding that as a small firm "it would be difficult trying to pick people straight from high school."

A follow up question: How likely do you think it is that there will be a replacement of tertiary education in accounting with on-the-job training because of the introduction of the four new technical modules? On a seven point Likert scale where one (1) depicts 'Very unlikely' to seven (7) 'Very likely', with a mean of 2.78 it appears that overall, respondents felt it was unlikely that tertiary education in accounting would be replaced with on-the-job training because of the introduction of the four new technical modules. This result stemmed from $39 \%$ of respondents feeling that it would be unlikely, no respondents feeling that it would be very likely, and only four respondents believing that it would be likely. These results are summarised in Figure 4. 
Figure 4. Respondents' perception of the likelihood that there will be a replacement of tertiary education in accounting with on-the-job training due to the four new technical modules

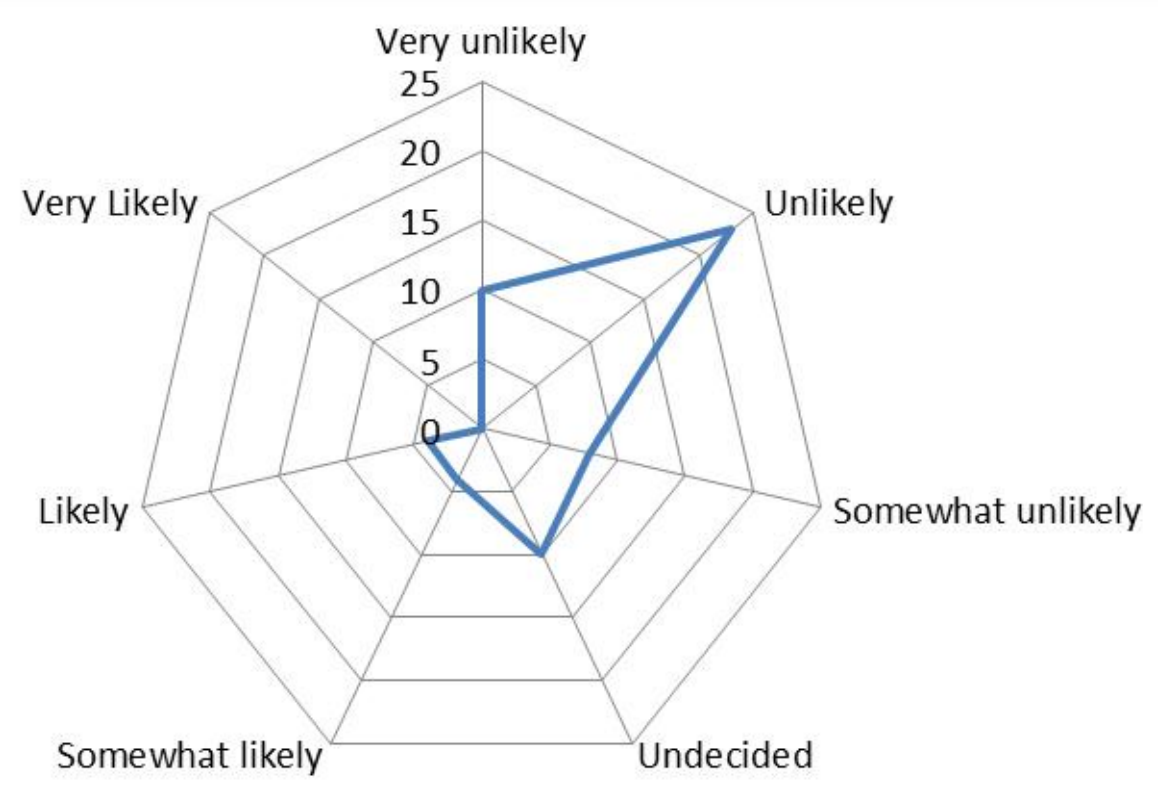

The majority of interview participants did not believe that on-the-job training should replace tertiary education. As Participant ' $B$ ' explained, "I think that they work hand and hand with each other.” Participant ' $Q$ ' remarked that "there are still major benefits of going to university, such as it showing you have internal motivation to learn." Participant ' $\mathrm{H}$ ' highlighted the importance of theory: "you definitely need that theory. It teaches you how to learn and how to research." Participant 'I' added that "there is no way that you can have a profession that doesn't have its basis out of university." Participant ' $K$ ' observed "like at primary school; first you learn to read, and then you read to learn. University is a way to learn how to learn.” A respondent to the open ended question provided the following observation:

Entering accounting jobs without any training beforehand causes issues for the working environment as a more experienced staff member then spends the majority of their time trying to teach the new person what to do and why we do it. We need tertiary education in order to form a foundation to work from. If people do not understand the simple things like debits and credits then they won't be hired as readily as someone that does.

Paisey and Paisey (2010) noted that work placement is advocated as a vehicle for more effectively developing skills such as communication and teamwork. Respondents were therefore asked to indicate a level of agreement on a 7 point Likert scale where one (1) depicts 'much worse' and seven (7) 'much better' to a series of statements accompanying the following question: What do you think the outcome would be if the requirements for a Chartered Accountants (CA) qualification changed to on-the-job training instead of tertiary education? The results are detailed in Table 7. 
Table 7. On-the-job training versus tertiary education

\begin{tabular}{lr}
\hline & Mean \\
\hline Level of professional status & 2.84 \\
\hline Ability for accounting graduates to make use of skills while learning them & 4.66 \\
\hline Level of flexibility of qualification & 4.12 \\
Level of alignment with other professional accounting bodies worldwide & 2.93 \\
Level of recognition worldwide of New Zealand Chartered Accountants & 2.98 \\
\hline Level of incentive for future accountants to pursue a CA membership & 4.53 \\
\hline Overall foundation of accounting knowledge for accounting graduates & 3.28 \\
\hline Level of public trust in the accounting profession & 2.83 \\
\hline
\end{tabular}

The results of the questions asked about the outcomes if the requirements for a CA qualification were changed to on-the-job training instead of tertiary education are summarised in Figure 5.

Howieson (2003, p. 100) noted that the "end objectives of innovations in accounting education will be to develop students' skills in abstraction, systems thinking, experimentation, and the capacity for communication and collaboration.” These types of skills were referred to as 'applied' skills by NZICA in their proposal document (NZICA 2010b).

Figure 5. What respondents thought the outcome would be if the requirements for a Chartered Accountants (CA) qualification changed to on-the-job training instead of tertiary education

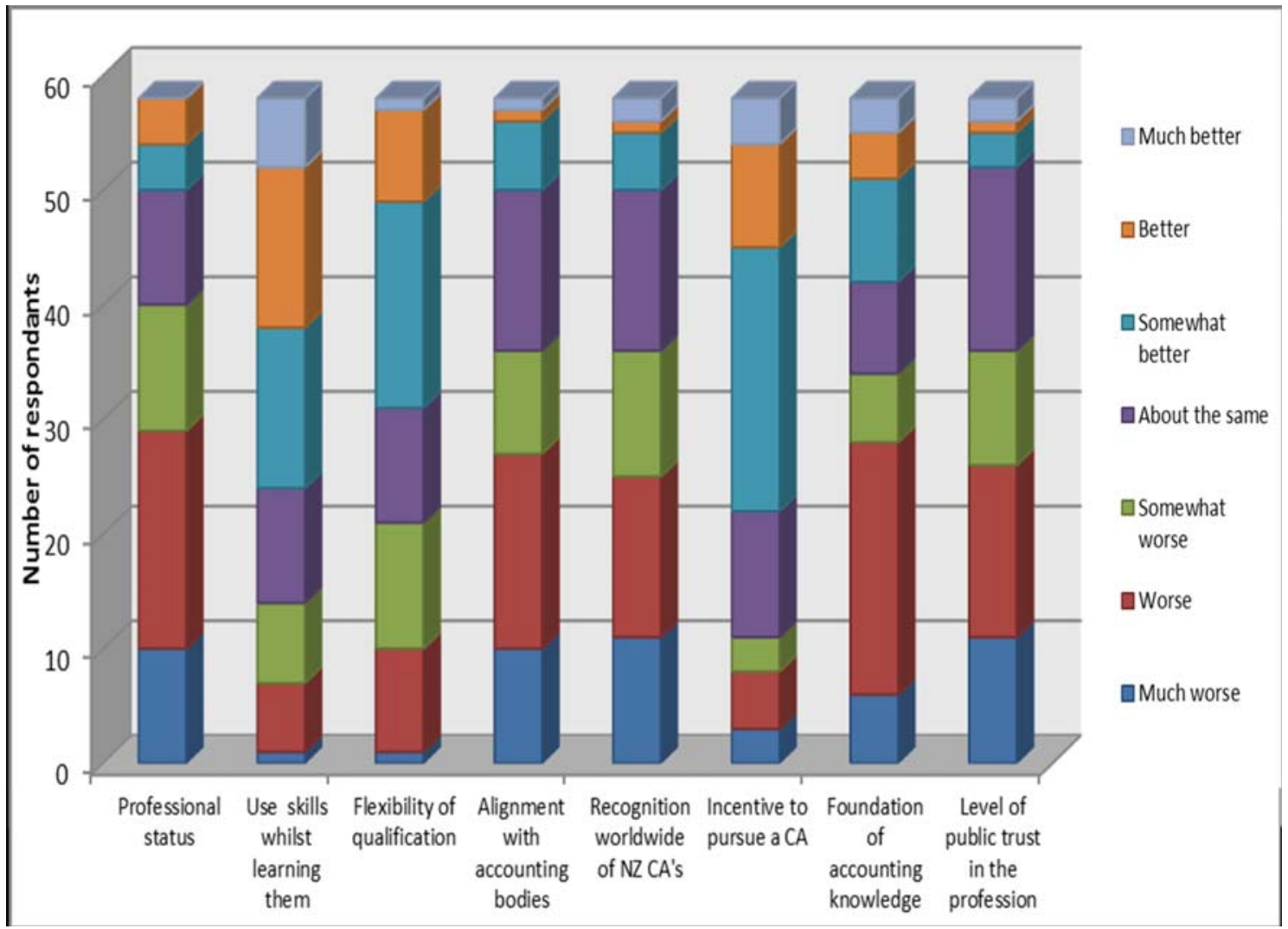


In order to effectively gauge whether respondents understand what the word 'applied' meant in this context, they were asked how they interpreted the word 'applied'. Thirty-seven percent of respondents interpreted 'applied' as more theory and less techniques, 56\% interpreted it as more techniques and less theory, $5 \%$ interpreted it as no techniques utilised, and one respondent stated that it meant "linking the theory to practice; showing and performing examples which illustrate theories in practice”. Another respondent noted in an open ended question that they believed "tertiary institutions should not be pressured to teach in an applied manner." They went on to say that institutions should "teach the theory properly and rigorously and if the student has a firm grasp, the application should not be too difficult in the real world."

As the respondents' interpretation of the word 'applied' was so variable, it was not surprising that the results were quite spread out when they were asked the question: To what extent do you agree that tertiary institutions should teach the four main compulsory topics (Financial Accounting, Management Accounting, Tax and Auditing) in a less 'applied' manner? Overall, respondents neither disagreed nor agreed, with a mean of 2.90. A cross tabulation was therefore conducted, in order to determine overall whether respondents preferred more theory and less techniques or more techniques and less theory. This revealed that respondents who believed applied meant more theory and fewer techniques neither agreed nor disagreed that the four main compulsory topics should be taught in a less applied manner. Furthermore, the respondents who believed applied meant more techniques and less theory, also neither agreed nor disagreed that four main compulsory topics should be taught in a less applied manner (with a mean of 2.97). Table 8 provides a summary of this cross tabulation.

Table 8. Comparison of respondents' interpretation of the word applied and the level to which they agree that tertiary institution should teach the four main compulsory topics in a less 'applied' manner

\begin{tabular}{|l|c|c|c|c|c|}
\hline & \multicolumn{5}{|c|}{ Meaning of applied } \\
& $\begin{array}{c}\text { More } \\
\text { theory, less } \\
\text { techniques }\end{array}$ & $\begin{array}{c}\text { More } \\
\text { techniques, } \\
\text { less theory }\end{array}$ & $\begin{array}{c}\text { No } \\
\text { techniques } \\
\text { utilised }\end{array}$ & $\begin{array}{c}\text { Solely } \\
\text { techniques } \\
\text { utilised }\end{array}$ & Other \\
Strongly disagree & 2 & 3 & 0 & 0 & 1 \\
Disagree & 7 & 10 & 1 & 0 & 0 \\
Neither agree nor disagree & 4 & 9 & 1 & 0 & 0 \\
Agree & 6 & 5 & 1 & 0 & 0 \\
Strongly agree & 2 & 5 & 0 & 0 & 0 \\
Mean & 2.95 & 2.97 & 3.00 & 0.00 & 1.00 \\
\hline
\end{tabular}

\section{Discussion and conclusion}

This paper set out to examine the perceptions of practitioners to the new directions being taken by NZICA with respect to the academic and professional requirements to obtain CA membership. It was found that accounting practitioners had varied opinions regarding the changes made by NZICA, and although many did not have a clear understanding of the changes, most found both positive aspects to the programme changes as well as aspects which caused concern. There is a high correlation between the findings in the online questionnaire survey and the interviews of the accounting practitioners' perceptions in accounting firms within New Zealand. It was revealed that, overall, both interview participants and survey respondents felt the changes were not significant for current 
members, but would be significant for future members. Both the respondents to the survey and interviewees believed that the NZICA Chartered Accountant academic requirements moving from a four year to a three year degree was not significant for clients or potential clients, due to reasons such as clients only knowing the brand, not what goes on behind it. However there were concerns being voiced from some participants that the changes would erode the brand and result in a degree which is less broad.

Results indicated that accounting practitioners believe that the barrier to entry into the accounting profession is high, but that this is a positive aspect as it helps to maintain quality. It was felt that the changes would reduce the barrier to entry. Overall, interview participants and survey respondents felt that three years should be the minimum length of tertiary education majoring in accounting; this aligns with the length of tertiary education required by ICAA and NZICA within the global alliance, however it is less than what is required by AICPA. The findings from the literature review, interview participants and survey respondents largely correlated regarding the importance of non-technical skills within an accounting degree, with benefits such as helping to build a rapport with clients and improving communication skills being noted. There was a contrast between the findings from the interview participants and the survey respondents regarding the impact that the four new technical modules will have on a firm that employs accounting graduates. Overall, interview participants felt the changes may reduce productivity and increase costs, whereas survey respondents neither agreed nor disagreed that the changes would negatively affect a firm that employs graduates. The findings demonstrated that accounting practitioners would like the four new technical modules to repeat the four compulsory topics taught at tertiary institutions, but stipulated that the technical modules should also combine practical with theory and should build on current knowledge. Some accounting practitioners felt that the four new technical modules would make a better accountant, but many interviewees also stated that it is the person's ethics which determine whether they are a good accountant or not. Both the survey respondents and interviewees felt overall that it was somewhat unlikely that the introduction of the four new technical modules would result in a replacement of tertiary education in accounting with on-the-job training, with reasons including the costs associated and the importance of a profession requiring tertiary education. Some significant issues were identified in this research, notably the issue of the level of graduates' maturity and the burden of costs on the accounting firm.

Thus, a key finding of this paper was that accounting practitioners believe that a degree in accounting has the ability to provide strong technical knowledge as well as develop nontechnical skills which are essential to produce a well-rounded accountant. Furthermore, practitioners feel that the changes made to the NZICA CA qualification may result in a degree which is not as broad, and an accountant who is not as well-rounded, due to the reduction in liberal papers. Furthermore, it is felt that the changes may cause confusion, devalue the brand and result in a lesser quality accountant overall. Another important finding was that accounting practitioners agreed overall that three to four years of accounting education at a tertiary institution is adequate, but four years would result in an accountant who was better-rounded due to the opportunity to complete liberal papers, developing nontechnical skills. The reduction in the length of the degree caused concern that graduates would not be as mature. Overall, accounting practitioners thought that the changes made by NZICA would attract more graduates, with respondents identifying both positive and negative aspects to this. They felt that the changes would harm the credibility of NZICA internationally; however, some practitioners did like the fact that NZICA was more aligned with Australia. 
Further, it was believed by practitioners that the new technical modules would offer more flexibility, and that the four technical modules should repeat the material taught at university to a certain extent, as long as a balance was kept between technical and applied knowledge, and that the technical modules built on the knowledge taught at university. However, it was felt that the changes would result in an increased onus on the employer, in terms of time and costs. Furthermore, accounting practitioners agreed that on-the-job training should not replace a tertiary qualification in accounting, but a balance should be maintained between the two. It was also believed that on-the-job training has the potential to make an accountant better-rounded. They identified some potential benefits of on-the-job training replacing tertiary education, which included students learning better by doing, but also noted that if there was no tertiary education in accounting, then a steep learning curve would be faced by entrants.

Finally, it was suggested by practitioners in their interview sessions that they should be kept better informed of changes by its Institute whereby any future research regarding new programmes being implemented by accounting professional bodies should be made more accessible to accounting practitioners, and that those affected by any proposed changes should have more opportunity to comment on the variations. They also felt that as accounting practitioners who do the employing of future accounting CA members that they should be consulted regarding the content of the four new technical modules, the compulsory topics required at tertiary institutions and other areas of the accounting degree programme. Furthermore, whilst developing the content, the study of ethics should be maintained throughout the qualification. Additionally, a high standard of quality must be maintained throughout the professional examinations in order to uphold the reputation of the accounting profession. Importantly practitioners also noted that small and medium sized firms should be offered additional support in order to make the transition successfully and to maintain the high level of quality among Chartered Accountants.

\section{Reference List}

Accounting Education Change Commission 1990, 'Objectives of education for accountants: Position statement number one', Issues in Accounting Education, vol. 5, no. 3, pp. 307312.

AICPA 1969, Committee on Education and Experience Requirements (The Beamer Committee), American Institute of Certified Public Accountants Report of the Committee on Education and Education Requirements for CPAs. New York, NY: AICPA.

Albrecht, W \& Sack, R 2000, Accounting education: Charting the course through a perilous future, vol. 16, American Accounting Association, Sarasota, FL.

Association of Chartered Certified Accountants 2011, ACCA Qualification, Association of Chartered Certified Accountants, Accessed 20 December 2011, http://www.accaglobal.com.

Ballantine, JA, \& Larres, PM 2004, 'A critical analysis of students' perceptions of the usefulness of the case study method in an advanced management accounting module: The impact of relevant work experience', Accounting Education: An International Journal, vol. 13, no. 2, pp. 171-189

Bedford, N, Bartholomew, E, Bowsher, C, Brown, A, Davidson, S, Horngren, C, Knortz, H, Piser, M, Shenkir, W, Simmons, J, Summers, E \& Wheeler, J 1986, 'Future accounting 
education: Preparing for the expanding profession', Issues in Accounting Education, vol. 1, no. 1, pp. 168-195.

Bhattacharjee, S, \& Shaw, L 2001, 'Evidence that independent research projects improve accounting students' technology-related perceptions and skills', Accounting Education: An International Journal, vol. 10, no. 1, pp. 83-103.

Breton, G 1999, 'Some empirical evidence on the superiority of the problem-based learning (PBL) method', Accounting Education: An International Journal, vol. 8, no. 1, pp. 1-12.

Cheng, RH, \& Saemann, G 1997, 'Comparative evidence about the verbal and analytical aptitude of accounting students', Journal of Accounting Education, vol. 15, no. 4, pp. 485-501.

Cleaveland, MC, \& Larkins, ER 2004, 'Web-based practice and feedback improve tax students' written communication skills', Journal of Accounting Education, vol. 22, no. 3, pp. 211-228.

CPA Australia. (2011). About CPA Program. CPA Australia, Accessed 15 December 2011, http://www.cpaaustralia.com.au

Creswell, J 2002, Educational research: Planning, conducting, and evaluating quantitative and qualitative research, Pearson Education, Upper Saddle Creek, NJ.

Creswell, J 2009, Research Design: Qualitative, Quantitative and Mixed Methods Approaches (3rd edition), SAGE Publications Inc., London, UK.

Crumbley, L, \& Smith, LM 2000, 'Using short stories to teach critical thinking and communication skills to tax students', Accounting Education: An International Journal, vol. 9, no. 3, pp. 291-296.

Davis, HZ, Hwang, L, \& Shoaf, V 2001, 'The use of individualised problems to improve students’ learning', Journal of Accounting Education, vol. 19, no. 3, pp. 189-210.

DeLange, P, Jackling, B, \& Gut, A 2006, 'Accounting graduates' perceptions of skills emphasis in Australian undergraduate accounting courses: an investigation from 2 Victorian universities', Accounting and Finance, vol. 46, pp. 365-386. http://dx.doi.org/10.1111/j.1467-629X.2006.00173.x

Donelan, JG, \& Philipich, KL 2002, 'Meeting the 150-hour requirement: The impact of curriculum choice on satisfaction', Accounting Education: An International Journal, vol. 20, no. 1, pp. 105-121

Fernández, W 2004, 'Using the Glaserian approach in grounded studies of emerging business practices’, Electronic Journal of Business Research Methods, vol. 2, no. 2, pp. 83-94.

Ferguson, J, Collison, D, Power, D, \& Stevenson, L 2005, 'What are recommended accounting textbooks teaching students about corporate stakeholders?' British Accounting Review, vol. 37, no. 1, pp. 23-46.

Flood, B, \& Wilson, R 2008, 'An exploration of the learning approaches of prospective professional accountants in Ireland', Accounting Forum, vol. 32, pp. 225-239. http://dx.doi.org/10.1016/j.accfor.2008.01.001

Friedlan, JM 1995, 'The effects of different teaching approaches on students' perceptions of the skills needed for success in accounting courses and by practicing accountants', Issues in Accounting Education, vol. 10, no. 1, pp. 47-63.

Gammie, E, \& Kirkham, L 2008, 'Breaking the link with a university education in the creation of a chartered accountant: The ICAS story', The British Accounting Review, vol. 40, no. 4, pp. 356-375. http://dx.doi.org/10.1016/j.bar.2008.06.002

Gammie, E, Cargill, E, \& Hamilton, S 2010, 'Searching for good practice in the development and assessment of non-technical skills in accountancy trainees-a global study', IAAER, pp. 1-115. 
Gardner, CT, Milne, MJ, Stringer, CP, \& Whiting, RH 2005, 'Oral and written communication apprehension in accounting students: Curriculum impacts and impacts on student performance', Accounting Education: An International Journal, vol. 14, no. 3, pp. 313-336.

Clayton, PR, \& Still, K 2004, 'Utilizing service learning in accounting programs', Issues in Accounting Education, vol. 19, no. 4, pp. 469-487.

Goodridge, E 2002, E-Learning Struggles to Make the Grade, InformationWeek, Accessed 10 December 2011, http://www.informationweek.com/story/IWK20020509S0011

Grace, DM, \& Gilsdorf, JW 2004, 'Classroom strategies for improving students' oral communication skills’, Journal of Accounting Education, vol. 22, no. 2, pp. 165-172.

Howieson, B 2003, 'Accounting practice in the new millennium: is accounting education ready to meet the challenge?', The British Accounting Review, vol. 35, no. 2, pp. 69-103. http://dx.doi.org/10.1016/S0890-8389(03)00004-0

Hunton, J 2002, 'Blending information and communication technology with accounting research', Accounting Horizons, vol. 16, no. 1, pp 55-67.

IAESB 2003, International education standard 3, professional skills, New York: International Accounting Education Standards Board, International Federation of Accountants, Retrieved 15 November 2011 http://www.ifac.org/.

IAESB 2006, Basis for Conclusions: IES 8, Competence Requirements for Audit Professionals, New York: International Accounting Education Standards Board, International Federation of Accountants, Retrieved 15 November 2011 http://www.ifac.org/.

Institute of Chartered Accountants in Australia 2011, The Chartered Accountants Program, Institute of Chartered Accountants in Australia Accessed 20 December 2011 www.charteredaccountants.com.au

Institute of Chartered Accountants in England and Wales 2011, Steps to the ACA, Institute of Chartered Accountants in England and Wales, Accessed 15 December 2011 careers.icaew.com.

Institute of Chartered Accountants of Scotland 2010, UK University Students; Entry Routes, Institute of Chartered Accountants of Scotland, Accessed 15 December 2011 www.icas.org.uk.

International Federation of Accountants Education Committee (IFAC). (2003). Introduction to international education standards. International Accounting Education Standards Board New York, Accessed 15 December 2011.

International Federation of Accountants Education Committee 1998, Competence-Based Approaches to The Professional Preparation of Accountants, New York.

International Federation of Accountants Education Committee 2003, Towards Competent Professional Accountants, New York.

Jackson, S, \& Durkee, D 2007, 'Incorporating information literacy into the accounting curriculum', Accounting Education: An International Journal, vol. 17, no. 1, pp. 83-97.

Kavanagh, M, \& Drennan, L 2008, 'What skills and attributes does an accounting graduate need? Evidence from student perceptions and employer expectations',Accounting \& Finance, vol. 48, no. 2, pp. 279-300. http://dx.doi.org/10.1111/j.1467629X.2007.00245.X

Kealey, BT, Holland, J, \&Watson, M 2005, 'Preliminary evidence on the association between critical thinking and performance in principles of accounting', Issues in Accounting Education, vol. 20, no. 1, pp. 33-50. 
Keim, MT, \& Grant, CT 2003, 'To tell or not to tell: An auditing case in ethical decision making and conflict resolution', Issues in Accounting Education, vol. 18, no. 3, pp. 315330.

Kennedy, FA, \& Sorensen, JE 2006, 'Enabling the management accountant to become a business partner: Organizational and verbal analysis toolkit', Journal of Accounting Education, vol. 24, no. 2/3, pp. 149-171.

Kern, BB 2001, 'Structuring financial statement analysis projects to enhance critical thinking skills development', Journal of Accounting Education, vol. 18, no. 4, pp. 341-353.

Kovar, SE, \& Evans, K 2001, 'The bakery: A cross-functional case study for introductory managerial accounting', Journal of Accounting Education, vol. 19, no. 4, pp. 283-303.

Kullberg, D, Gladstone, W, Scanlon, P, Cook, J, Groves, R, Horner, L, O’Malley, S, \& Kangas, E 1989, Perspectives on Education: Capabilities for Success in the Accounting Profession (The Big 8 White Paper), American Accounting Association, Retrieved 20 December 2011 http://aaahq.org/aecc/history/appB.htm Lahn, L \& Jensen, K 2006, 'Models of professional learning. Exploring the epistemic tool perspective', Knowledge, Work and Society, vol. 4, no. 3, pp. 63-82.

Lindberg, DL 1999, 'Instructional case: Lakeview Lumber, Inc.: A study of auditing issues related to fraud, materiality and project judgement', Issues in Accounting Education, vol. 14, no. 3, pp. 497-516.

Maher, MW 2000, 'Management accounting education at the millennium', Issues in Accounting Education, vol. 15, no. 2, pp. 335-347.

Malthus, S, \& Fowler, C 2009, 'Perceptions of accounting: a qualitative New Zealand study’, Pacific Accounting Review, vol. 21, no. 1, pp. 26-47. http://dx.doi.org/10.1108/01140580910956849

Manninen, A 1997, 'Critical reading in accounting', Accounting Education: An International Journal, vol. no. 4, pp. 281-294.

Marriott, N, \& Mellett, H 1994, 'Introducing spreadsheets into an intermediate financial accounting course: The results of a quasi-experiment', Accounting Education: An International Journal, vol. 3, no. 4, pp. 297-311.

Mathews, M 2001, 'The way forward for accounting education? A comment on Albrecht and Sack 'A Perilous Future', Accounting Education, vol. 10, no. 1, pp. 117-122. http://dx.doi.org/10.1080/09639280110050277

Milner, M, \& Hill, W 2008, 'Examining the skills debate in Scotland', International Journal of Management Education, vol. 6, no. 3, p. 13.

Nathan, S, \& Dunn, KA 1997, 'Business press articles and higher level learning skills in accounting courses’, Education and Training, vol. 39, no. 5, pp. 189-194.

Nettleton, S, Litchfield, A, \& Taylor, T 2008, 'Engaging professional societies in developing work-ready graduates', Higher Education Research and Development Society of Australasia, Inc. HERDSA 2008 conference proceedings, Retrieved 10 December 2011 http://www.herdsa.org.au/wp-content/uploads/conference/2008/papers/

Nikolai, LA 1996, 'Suggestions for educational research on improving thinking and communication skills of accounting students', Journal of Accounting Education, vol. 14, no. 2, pp. 193-197.

NZICA 2010a, How to become a Chartered Accountant, New Zealand Institute of Chartered Accountants, Accessed 10 December 2011 www.nzica.com.

NZICA 2010b, Proposed CA Program and academic requirements, New Zealand Institute of Chartered Accountants, Accessed 10 December 2011 www.nzica.co.nz.

NZICA 2011a, About the new Program, New Zealand Institute of Chartered Accountants, Accessed 10 December 2011 www.nzica.com. 
NZICA 2011b, A message from the Chief Executives, New Zealand Institute of Chartered Accountants, Accessed 10 December 2011 www.nzica.com.

Paisey, C, \& Paisey, NJ 2005, 'Improving accounting education through the use of action research', Journal of Accounting Education, vol. 23, no.1, pp. 1-19.

Paisey, C, \& Paisey, N 2010, 'Developing skills via work placements in accounting: Student and employer views', Accounting Forum, vol. 34, no. 2, pp. 89-108.

http://dx.doi.org/10.1016/j.accfor.2009.06.001

Phillips, F 2001, 'A research note on accounting students' epistemological beliefs, study strategy and unstructured problem-solving performance', Issues in Accounting Education, vol. 16, no. 1, pp. 21-40.

Potter, BN, \& Johnston, CG 2006, 'The effect of interactive on-line learning systems on student learning outcomes in accounting', Journal of Accounting Education, vol. 24, no. 1, pp. 16-34.

Reeve, J 1983, 'The Five-Year Accounting Program as a Quality Signal', The Accounting Review, vol. 58, no. 3, p. 639.

Requirements for British Chartered Accountants 1992, The CPA Journal, vol. 62, no. 5, p. 15.

Samkin, G, \& Francis, G 2008, 'Introducing a learning portfolio in an undergraduate financial accounting course', Accounting Education: An International Journal, vol. 17, no. 3, pp. 233-271.

Sangster, A, \& Mulligan, C 1997, 'Integrating the world wide web into an accounting systems course', Accounting Education: An International Journal, vol. 6, no. 1, pp. 5362.

Sawyer, AJ, Tomlinson, SR, \& Maples, AJ 2000, 'Developing essential skills through case study scenarios', Journal of Accounting Education, vol. 18, no. 3, pp. 257-282.

Simons, K,\& Higgins, M 1993, 'An examination of practitioners' and academicians' views on the content of the accounting curriculum', Accounting Educators' Journal, vol. 5, no. 2, Fall, pp. 24-34.

Smythe, M, \& Nikolai, LA 1996, 'Communication concerns across different accounting constituencies', Journal of Accounting Education, vol. 14, no. 4, pp. 435-451.

Smythe, M, \& Nikolai, LA 2002, 'A thematic analysis of oral communication concerns with implications for curriculum design', Journal of Accounting Education, vol. 20, no. 3, pp. 163-181.

Tan, L, Fowler, M, \& Hawkes, L 2004, 'Management accounting curricula: striking a balance between the views of educators and practitioners', Accounting Education, vol. 13, no. 1, pp. 51-67. http://dx.doi.org/10.1080/0963928042000201293

Tan, L, \& Laswad, F 2006, 'Students' beliefs, attitudes and intentions to major in accounting', Accounting Education, vol. 15, no. 2, pp. 167-187. http://dx.doi.org/10.1080/09639280600787194

Tashakkori, A \& Teddlie, C 1998, Mixed Methodology: Combing Qualitative and Quantitative Approaches, Sage, London.

Turner, D 2010, 'Qualitative interview design: A practical guide for novice investigators', The Qualitative Report, vol. 15, p. 3, pp. 754-760.

Weil, S, Oyelere, P, \& Rainsbury, E 2004, 'The usefulness of case studies in developing core competencies in a professional accounting programme: A New Zealand study', Accounting Education: An International Journal, vol. 13, no. 2, pp. 139-169.

Weisenfeld, L, \& Robinson-Backmon, I 2001, 'Minority accountants' views on gender and race biases, career limitations and suggestions for undergraduate educational institutions’, Journal of Accounting Education, vol. 19, no. 3, pp. 163-187. 
Whitham, RB 1974, 'Five years of university education not required', Journal of Accountancy, vol. 138, no. 3, pp 93-96.

Wolcott, SK, Baril, CP, Cunningham, BM, Fordham, DR, \& St. Pierre, K 2002, 'Critical thought on critical thinking research', Journal of Accounting Education, vol. 20, no. 2, pp. 185-203.

Zaid, OA, \& Abraham, A 1994, 'Communication skills in accounting education: perceptions of academics, employers and graduate accountants', Accounting Education: An International Journal, vol. 3, no. 3, pp. 205-221.

Zraa, W, Kavanagh, M, \& Hartle, R 2011, 'Teaching accounting in the new millennium', Paper presented at the Cambridge Business and Economics Conference, 27-29 June 2011, Cambridge, UK, Retrieved 20 December 2011 www.facultyforum.com/cbec/2011CBECProceedings. 